\title{
Suomen lapsilisäjärjestelmä
}

\author{
Kirjoittanut V.J. Sukselainen.
}

Perhepalkasta lapsilisään.

Vaikka maassamme jo vuonna 1943 oli säädetty perhelisä-, laki, jonka pohjalla yleinen perhekustannusten tasaus olisi voitu toteuttaa poistamalla siitä oikeutta perhelisän saantiin supistava tulo- ja lapsiraja ja korottamalla määrää, jouduttiin yleinen perhekustannusten tasaus eli lapsilisäjärjestelmä omaksumaan vuonna 1948 ikäänkuin kiertoteitse. Tasaus tuli näet ensiksi palkannauttijaväestön kohdalta yleiseksi ja määrältään perhelisää monin verroin suuremmaksi, kun syksyllä 1947 äkkiä ja valmistelematta otettiin käytäntöön ns. perhepalkkausjärjestelmä.

Virike tähän ratkaisuun tuli työnantajataholta. Työnantajat olivat syyskesällä 1947 huolestuneita uhkaavasta yleisestä palkankorotuksesta, jota vastaavien hinnankorotusten tiedettiin olevan vaikeuksien takana. Etsittäessä keinoa, millä rahan arvoa alentava ja yrittäjän toimintamahdollisuuksia heikentävä inflaatioaalto torjuttaisiin, huomio kiintyi ulkomaiden perhepalkkausjärjestelmiin, joiden työnantajille tarjoamista eduista oltiin tietoisia. Siksipä heitettiin esiin ajatus yleisen palkankorotuksen korvaamisesta palkkaan liittyvillä perhelisillä. Kun Suomen Ammattiyhdistysten Keskusliitto perinteellisesti oli sillä kannalla, että samasta työstä on maksettava sama palkka, asiasta ei näyttänyt tulevan mitään. Ehdotuksen myönteiset 
puolet olivat kuitenkin herättäneet siksi paljon mielenkiintoa hallituksen keskuudessa, että työnantajain tarjousta ei haluttu jättää käyttämättä. Silloin keksittiin ratkaisu, jota monesta syystä voidaan pitää liian keveästi tehtynä, mutta joka mursi SAK:n vastustuksen. Hallitus valitsi sen tien, että antoi sekä palkankorotuksen että perhelisät. Työnantajapiireille lienee ollut melkoinen yllätys, kun valtioneuvosto syyskuun 26 päivänä 1947 tekemässään palkkojen järjestelyä koskevassa päätöksessä mainitsi, että »elinkustannuksia paremmin vastaavan palkkauksen aikaansaamiseksi on otettava käytäntöön ns. perhepalkkajärjestelmä» sekä tiedoitti kehoittaneensa työmarkkinajärjestöjä sopimaan sellaisesta järjestelystä, jonka mukaan 1. lokakuuta 1947 alkaen suoritetaan kaikille niille työntekijöille, joilla on lapsia huollettavanaan, jokaiselta lapselta perhelisää niinkuin valtion viran ja toimenhaltijoille maksetaan eli 500 markkaa kuukaudessa. Varat tätä tarkoitusta varten olisi kerättävä siten, että työnantajat suorittąvat määräprosentin maksamistaan palkoista erityiseen rahastoon.

Kun työnantajain toimesta asiaa oli ajettu tarmokkaasti ja $\mathrm{mm}$. suositeltu eduskunnan puhujalavalta vielä samana päivänä, jona valtioneuvosto teki ratkaisunsa, heillä ei ollut muuta mahdollisuutta kuin tyytyä tehtyyn päätökseen. Eihän se sitäpaitsi merkinnyt muuta, kuin että uusi järjestelmä alkaisi vaikutuksensa yhtä palkankorotusta myöhemmin kuin mitä työnantajataholla alkuaan oli toivottu. Koska tällä tempulla oli saatu toisen asiapuolen suostumus, työnantajilla ei oikeastaan ollutkaan valittamista. Kun hallitus kuitenkin jätti asian ajamisen työmarkkinajärjestöille lähettämänsä kirjeen varaan, kesti molemminpuolinen hämmästys työmarkkinajärjestöissä kolmisen viikkoa. Vasta lokakuun 21 päivänä kokoontuivat työmarkkinajärjestöjen edustajat yhdessä eräiden asiantuntijoiden kanssa keskustelemaan siitä, miten mainitun kuukauden alusta alkavaksi' tarkoitettu järjestelmä saataisiin käyntiin. Molemmat osapuolet tulivat kuitenkin heti ensimmäisessä neuvottelussa yksimielisiksi siitä, että ne eivät halunneet hoitaa asiaa keskinäisellä sopimuksella, jolloin järjestelmä olisi rajoittunut vain jär- 
jestäytyneihin työnantajiin ja työntekijöihin. Pidettiin mahdollisena, että olisi voinut tapahtua eroamisia työnantajajärjestöstä ja pohja olisi näin entisestään kaventunut. Sentähden haluttiin lainsäätäjän apua.

Jo tässä ensimmäisessä neuvottelussa heitettiin liiketyönantajain taholta esille ajatus, että määräys perhepalkasta olisi pitänyt ottaa itse palkansäännöstelypäätökseen, koska sellainen menettely olisi järjestäytyneiden työnantajain kannalta saattanut asian tukevalle pohjalle. Ammattiyhdistysliikkeen taholla tällaista järjestelyä kuitenkin pidettiin mahdottomana, koska asian tekeminen työnantajan ja työntekijän väliseksi heikontaisi suuresti perheellisen työläisen asemaa ja työnspantimahdollisuuksia. Neuvottelu johti siihen, että sovittaisiin työmarkkinajärjestöjen kesken asiaa valmistelevan komitean kokoonpanosta ja pyydettäisiin valtioneuvostoa nimittämään tällainen komitea laatimaan niitä lainsäännöksiä, jotka se asian hoitamiseksi katsoo tarpeellisiksi. Tällainen komitea asetettiinkin sitten lokakuun 30 päivänä.

Valtioneuvosto ei kuitenkaan jäänyt odottamaan asettamansa komitean kannanottoa, vaan teki jo marraskuun 8 päivänä väliaikaisen ratkaisun lisäämällä työpalkkojen säännöstelystä annettuun päätökseen uuden (10 a) pykälän, jossa määrättiin maksettavaksi lokakuun 1 päivästä alkaen sihen asti, kunnes erityinen lainsäädäntö lapsilisän maksamisesta on saatu aikaan, jokaiselle yksityisoikeudellisessa työsuhteessa olevalle työntekijälle ja toimihenkilölle, joka on perheensä pääasiallinen huoltaja, lapsilisä kustakin tämän elätettävänä olevasta alle 17vuotiaasta omasta tai aviopuolison lapsesta tai ottolapsesta. Lapsilisän suuruudeksi määrättiin 500 markkaa kuukaudessa säännöllisessä työssä olevalle, lyhytaikaisessa tai kausiluontoisessa työssä olevien piti saada 2: 50 työtunnilta, ei kuitenkaan enempää kuin 500 markkaa kuukaudessa. Samalla säädettiin, että työnantajalla ei ole oikeutta irtisanoa työntekijäänsä tai toimihenkilöänsä lapsilisämaksuvelvollisuutensa johdosta. Tällainen selvä määräys ratkaisi pulman järjestäytyneitten suurtyönantajain kohdalta varsin tyydyttävästi. Ne epäkohdat, mitkä 
asian jättäminen työntekijän ja työnantajan keskeiseksi toi mukanaan, kohdistuivat lähinnä pientyönantajiin, joille järjestelmästä koituva taloudellinen rasitus jakaantui kovin epätasaisesti. Sensijaan joutui SAK tämän järjestelyn yhteydessä luopumaan siitä vastustavasta kannastaan, josta edellä on mainittu. Tämä kannanmuutos näyttää aiheutuneen eräänlaisesta vaihtoehtojen vertailusta. Kun ei näyttänyt olevan muuta mahdollisuutta saada järjestelmää käyntiin jo lokakuun alusta, kuten oli luvattu, SAK joutui tekemään valintansa tarjolla olevan edun ja niiden haittojen välillä, jotka tähän etuun huomattiin liittyvän. Kun ei ollut odotettavissa, että uusi järjestelmä suurtyönantajain kohdalla johtaisi työläisten irtisanomiseen, korkeintaan vaikeuttaisi työpaikan vaihtoa, SAK lienee katsonut parhaiten valvovansa jäsentensä enemmistön etua hyväksyessään ajatuksen ja turvatessaan keskeisimmille työläisryhmille perhelisän jo lokakuun alusta alkaen.

Epäkohta muodostui erityisen raskaaksi pientyönantajille, sillä jo yksi ainoa lapsirikas työntekijä saattoi aiheuttaa, että rasitus jollekin työnantajalle tuli kohtuuttoman raskaaksi, kun taas sellainen työnantaja, joka oli karttanut lapsirikkaiden perheiden ottamista palvelukseensa, välttyi kaikelta rasitukselta. Tästä syystä esim. maataloustyönantajain järjestö aluksi katsoi, ettei se voi kehoittaa jäseniään lapsilisän maksamiseen, ennenkuin on saatu takeet siitä, että jonkinlainen tasoitus saadaan hallituksen toimesta aikaan.

Lokakuun lopulla asetettu perhepalkkakomitea työskenteli nopeasti ja jätti jo joulukuun 8 päivänä mietintönsä, jossa se esitti tasausrahaston perustamista. Jokaisen työnantajan olisi tullut kutakin työntekijäänsä kohden suorittaa maksu, jonka suuruuden valtioneuvosto olisi määrännyt. Suoritus olisi tapahtunut kiinnittämällä verokirjaan erityisiä lapsilisämerkkejä. Valvontavaikeuksien helpottamiseksi komitea esitti, että tasausmaksua ei laskettaisi prosentteina palkasta, vaan määräsummana työntekijää kohden. Riittävänä maksuna komitea piti 325 markkaa kuukaudessa työntekijältä. Rahasto olisi tullut lapsilisärahaston nimisenä Postisäästöpankin hoidettavaksi. 
Perhepalkkakomitea kiinnitti mietinnössään myös huomiota siihen, että suunniteltu järjestelmä jättäisi varsin suuren osan lapsenhuoltajia vaille sitä tukea, johon he epäilemättä olisivat yhtä oikeutettuja kuin varsinaiset palkkatyön tekijät. Komitean mielestä olisi parempi korvata perhepalkkausjärjestelmá yleisellä kaikkiin kansalaispiireihin ulottuvalla lapsilisäjärjestelmällä, samantapaisella, joka Ruotsissa oli astuva voimaan vuoden 1948 alusta. Hahmottelipa se tämäntapaisen järjestelmän rahoitusmahdollisuuksiakin.

Sinä aikana, jona perhepalkkakomitea valmisteli mietintöänsä, mielipiteet hallituksen keskuudessa olivatkin vähitellen alkaneet kypsyä siihen suuntaan, että väliaikaista perhepalkkausjärjestelmää ei pitäisi vakinaistaa, vaan olisi siirryttävä yleiseen lapsilisäjärjestelmään. Tämän ajatuksen olivat hallituksen maalaisliittolaiset jäsenet esittäneet jo vastustaessaan syyskuun 26 päivän palkkapäätöstä. Pientyönantajille ja heidän palveluksessaan oleville epäedullinen väliaikainen järjestely oli syksyn mittaan terästänyt järjestelmän ulkopuolelle jääneiden väestöpiirien vastustushenkeä. Niinpä oli hallitus maataloustuotteiden hintajärjestelyjen yhteydessä joutunut antamaan lupauksen, että se tutkii, mitä mahdollisuuksia on ulottaa suunniteltu järjestelmä myös omaa työtään tekevää viljelijäväestöä koskevaksi. Kun kävi selväksi, että asiaa ei voitu hoitaa työmarkkinajärjestöjen keskeisellä. sopimuksella, vaan että se olisi tuotava eduskuntaan, käsittivät kummankin työväenpuolueen johtavat miehet, että tällainen lainsäädäntö olisi ollut poliittinen mahdottomuus, koska näihinkin puolueisiin lukeutui suuri määrä omaa työtään tekevää väkeä. Sentähden hallitus ei ryhtynytkään mihinkään toimenpiteisiin puheena olevan komiteamietinnön johdosta vaan asetti uuden komitean suunnittelemaan yleistä lapsilisäjärjestelmää.

Tämä pääsi aloittamaan työnsä tammikuun puolivälissä 1948 ja sai mietintönsä valmiiksi helmikuun 21 päivänä. Komitea esitti säädettäväksi lapsilisälain, jonka mukaan jokaisesta alle 16-vuotiaasta lapsesta maksettaisiin lapsilisää 600 markkaa kuu- 
kaudessa eli 7.200 markkaa vuodessa. Tällä korvattaisiin sekä perhepalkkausjärjestelmä että ns. tukipalkkioita poistettaessa käytäntöön otettu maitotaloustuotteiden hinnanalennusjärjestelmä. Kun perhepalkan ja hinnanalennuskortin yhteinen arvo vuoden 1948 alussa oli noin 9.500 markkaa vuodessa, komitean ehdotus merkitsi itse asiassa etuuksien vähentämistä niiltä, jotka olivat pảlkannauttijoita eivätkä olleet karjataloustuotteisiin nähden omavaraisia. Kun molemmat edellä mainitut etuudet kuitenkin juriidisesti olivat verotettavaa tuloa ja lapsilisä esitettiin verovapaaksi, komitea katsoi, että sadan markan korotus kuukausimaksuun olisi kohtuullinen korvaus menetetystä edusta. Samanaikaisesti saisivat tämän korotetun maksun nekin lapsenhuoltajat, jotka perhepalkkajärjestelmä oli jättänyt kokonaan osattomiksi. Tämä merkitsi lapsilisästä osallisiksi tulevien lasten määrän kaksinkertaistumista.

Kun lapsilisään oikeutettuja lapsia arvioitiin olevan 1.142.500, varojen kokonaistarve oli noin 8,2 miljardia markkaa. Tästä summasta lapsilisäkomitea esitti hankittavaksi tuloja menoarvion puitteissa 3,25 miljardia siten, että hinnanalennusjärjestelmän poistaminen säästäisi noin 2,5 miljardia markkaa vuodessa, valtion palveluksessa olevien henkilöiden perhelisiä varten budjetissa oli varattu 550 milj. markkaa ja lopuksi perhelisälakia muutettaisiin niin, että perhelisä annettaisiin vasta viidennestä lapsesta, jolloin säästyisi 200 milj. markkaa. Puuttuvat 5 miljardia komitea esitti hankittavaksi erityisellä työnantajien maksettavaksi pantavalla lapsilisämaksulla, joka kannettaisiin työnantajan kansaneläkemaksun yhteydessä siten, että tämä korotettaisiin yhdestä viiteen prosenttiin palkkasummasta.

Ehdotettu lapsilisämaksu olikin ainoa, mikä komitean ehdotuksessa vielä muistutti edellisenä syksynä käytäntöön otetusta perhepalkkausjärjestelmästä. Varsinaisena virikkeenä tämän tapaisen rahoitusmenetelmän esittämiseen olikin juuri vallitseva käytäntö. Kun järjestyneet työnantajat olivat oma-aloitteisesti tarjoutuneet maksamaan lapsilisää ja tämäntapainen järjestely 
jo oli sopeutunut vallitsevaan hinta- ja palkkasäännöstelyyn, komitean piirissä lienee ajateltu, että työnantajat saisivat ansiotonta etua, jos heidät nyt vapautettaisiin kaikesta osallistumisesta lapsilisien rahoitukseen, vaikka moni jo on saattanut hankkia itselleen vastaavan hintaedun. Psykologisestikin on ymmärrettävää, että varsinkin työväestön edustajain taholla kernaasti nähdään työnantajain entistä runsaammin osallistuvan työläisten hyväksi koituvien rahavarojen keruuseen.

Tilanne oli sitäpaitsi työnantajainkin kannalta sikäli edullinen, että ehdotettu järjestely merkitsi pientyönantajalle suurta parannusta vallitsevaan käytäntöön. Suurtyönantajalle uusi ehdotus tiesi rasituksen nousua vain siinä tapauksessa, että keskipalkka oli korkea ja lapsia erityisen vähän. Ehdotettu lapsilisämaksu merkitsi näissä olosuhteissa entisen rasituksen oikeudenmukaistamista eikä uuden luomista. Rahoitustapa oli jatkuvaa inflaatiotakin ajatellen sikäli edullinen, että se oli ikäänkuin luonnostaan indeksiin sidottu. Mikäli palkat nousisivat, sikäli myös tasoitusmaksut suurenisivat ja valtiolla olisi mahdollisuus suurentaa lapsilisää.

Maaliskuun alussa 1948 hallitus antoi eduskunnalle esityksen lapsilisälaiksi. Esitys rakentui pääasiassa lapsilisäkomitean mietinnön pohjalle. Ainoastaan perhelisälain supistamisesta oli luovuttu ja jokin vähäinen muutos tehty. Eduskuntakäsittely vei suhteellisen paljon aikaa, sillä valtiovarainvaliokunnalla, jolta työväenasiainvaliokunta pyysi lausuntoa, oli verraten paljon huomauttamista varsinkin esitettyä rahoitustapaa vastaan. Kansaneläkemaksujen kannosta saatujen kokemusten katsottiin viittaavan siihen, että veronkavallusten määrä tulee nousemaan, kun työnantajan kohdalta houkutus tulee huomattavasti suuremmaksi. Lisäksi pelättiin sitä työnlisäystä, minkä uusi järjestelmä tulisi verolautakunnille aiheuttamaan.

Valtiovarainvaliokunta katsoikin voivansa puoltaa esityksen hyväksymistä vain siinä muodossa, että lapsilisää annettaisiin vasta toisesta lapsesta lähtien, kuten aikaisemmin oli ollut asian laita myös valtion viran ja toimen haltijoille perhelisää makset- 
taessa. Täten arvioitiin syntyvän säästöä noin 2,5 miljardia markkaa. Työnantajain lapsilisämaksu olisi tällöin voitu alentaa kahteen prosenttiin ja valtiovarainvaliokunnan pelkäämät epäkohdat jääneet pienemmiksi. Toinen periaatteellisesti tärkeä kohta, johon valtiovarainvaliokunta asettui kielteiselle kannalle, oli lapsilisän verovapaus. Mitään varsinaista perustetta valiokunta ei kuitenkaan esittänyt, se vain halusi pitää asian avoimena siihen saakka, kunnes perheellisyyden perusteella annetut verohuojennukset voitaisiin ottaa uudelleen harkittaviksi. Pyrkimys oli ilmeisesti päästä samanlaiseen järjestelyyn, joka Ruotsissa yleisen lapsilisän säätämisen yhteydessä otettiin käytäntöön ja jota seuraavassa tämän julkaisun kirjoituksessa yksityiskohtaisesti selostetaan.

Valtiovarainvaliokunnan on täytynyt olla itsekin tietoinen siitä, että sen muutosehdotukset eivät vallitsevissa olosuhteissa olleet toteutettavissa. Kun lapsilisä jo oli käytännössä perhepalkkauksen muodossa, lapsilisän kieltäminen ensimmäiseltä lapselta olisi merkinnyt huomattavaa palkanalennusta kaikille perheellisille, eikä ollut odotettavissa, että työmarkkinat silloisissa oloissa olisivat pysyneet rauhallisina, jos tällaiseen olisi ryhdytty. Tuskin myös oli riittävästi perusteltua esittää lapsilisän jättämistä verotettavaksi tuloksi. Sehän olisi veroprogression takia merkinnyt lapsilisän antaman tuen jatkuvaa pienenemistä perheen lapsiluvun suuretessa.

Työväenasiainvaliokunta tulikin näistä syistä mietinnössään takaisin hallituksen eli lapsilisäkomitean linjalle sekä ensimmäisen lapsen lapsilisässä että verovapauskysymyksessä. Lapsilisämaksu aiheutti kuitenkin niin paljon erimielisyyttä, että valiokunta tyytyi esittämään lapsilisän maksamista valtion varoista ja esitti ehdotuksen laìksi lapsilisämaksusta hyljättäväksi. Kun asia sitten tuli suureen valiokuntaan, saatiin eri mielipidesuuntien välillä aikaan sellainen sovintoratkaisu, että lapsilisälaki hyväksyttiin jokseenkin hallituksen esittämässä muodossa, mutta laki lapsilisämaksusta ainoastaan määräaikaisena, vuoden 1950 loppuun ulottuvana. Katsottiin, että muutaman vuoden 
kuluttua saattaa valtiolla olla paremmin kuin nyt mahdollisuuksia käyttää lapsilisien rahoittamiseen muista verolähteistä kertyviä tuloja, jotta uutta veroa ei tarvitse tehdä pysyväiseksi.

Siten saatiin lapsilisälaki hyväksytyksi kesäkuun alkupuolella ja annettiin heinäkuun 22 päivänä. Se määrättiin astuvaksi voimaan lokakuun 1 päivänä 1948. Näin sai Suomi kahta vuotta myöhemmin kuin Norja ja vajaata vuotta myöhemmin kuin Ruotsi lapsilisälain, vaikka se vuoden 1943 perhelisälailla oli ollut perhekustannusten tasaamiseen tähtäävien pyrkimysten uranuurtajana Pohjoismaissa.

Siirryttäessä yleiseen lapsilisään sulautuivat siihen myös ne perhepalkkauksen muodot, joita valtio oli ennen syksyä 1947 soveltanut. Tällaisia olivat kansakoulunopettajain kasvatusapu, joka otettiin käytäntöön vuonna 1908, sekä valtion viran ja toimen haltijain vuonna 1923 vakinaistettu perhelisä. Sensijaan papit ja kanttoriurkurit jäivät lapsilisälain ulkopuolelle niin pitkäksi aikaa kuin heille maksetaan vuoden 1944 lain perusteella kasvatusapua. Syynä viimeksimainittuun poikkeukseen oli kirkon lainsäädäntöä vaikeuttava erikoisasema.

Miksi perhelisälakia ei kumottu?

Niinkuin edellä jo on tullut sanotuksi, vuoden 1943 perhelisälaki ei paljonkaan eroa vuoden 1948 lapsilisälaista muussa kuin siinä, että se rajoittuu vähävaraisimpiin ja lapsirikkaimpiin perheisiin. Näin ollen olisi tuntunut loogilliselta, että uuteen järjestelmään olisi siirrytty vanhaa kehittämällä eikä rinnakkaisjärjestelmän luomisella. Tämä ajatus tuotiin lapsilisäjärjestelmää valmisteltaessa useassakin yhteydessä esiin. Jo lapsilisäkomitea käsitteli asiaa, mutta Väestöliiton taholta esitettyjen näkökohtien takia se rajoittui ainoastaan esittämään perhelisälain supistamista vähintään 5-lapsisiin perheisiin elikkä samaan laajuuteen, mikä alkuperäisellä vuoden 1943 lailla oli ollut. Hallitus hyväksyi esityksessään Väestöliiton kannan, eikä kajonnut ollenkaan perhelisälakiin. Eduskuntakäsittelyn 
yhteydessä asia kyllä oli eri vaiheissa esillä, mutta ajatus perhelisälain kumoamisesta ei saanut yleisempää kannatusta osakseen.

Pääasiàllisena syynä siihen, että perhelisälaki säilyi, on pidettävä luontoissuoritusmuotoa, josta viiden vuoden aikana oli saatu hyviä kokemuksia. Väestöliiton, sosiaaliministeriön ja kansanhuoltoministeriön yhteistyöllä oli onnistuttu kehittämään lapsirikkaisiin koteihin sopivia tarviketyyppejä, toimittamaan perhelisävarojen turvin lastenvaatteiden ja vuodevaatteiden erikoisjakeluja sekä viljelyshuoltoa kehittämällä ja muilla vastaavilla menetelmillä lisäämään perheiden omatoimisuutta ja aikaansaamaan siten pysyvää paranemista niiden elinehdoissa. Jos perhelisälaki olisi kumottu, tällainen toiminta olisi tullut vaikeaksi. Toisaalta ei olisi ollut perusteltua syytä ulottaa luontoissuoritusta kaikkiin lapsilisää nauttiviin perheisiin, eikä tavaratilannekaan olisi tehnyt mahdolliseksi sellaisten tarvikemäärien varaamista Väestöliiton käyttöön, että jakelu olisi voitu ulottaa kaikkiin lapsiin. Tuntui näin ollen luonnolliselta rajoittaa erikoistoimenpiteet jatkuvasti suurimpiin, köyhimpiin ja tarvikepulasta tästä syystä eniten kärsineisiin perheisiin. Tällaiselle toiminnalle tarjosi perhelisälain säilyttäminen sopivat puitteet. Jos perhelisälaki olisi kumottu, lapsilisälain alaiset perheet olisi varallisuuden perusteella pitänyt jakaa kahtia. Varakkaammat olisivat saaneet käteistä, vähävaraisemmat luontoissuorituksen. Tällaista menettelyä ei saatettu pitää onnistuneena.

Perhelisälain säilyttäminen merkitsee, että suurimmat ja vähävaraisimmat perheet tulevat saamaan jonkin verran suuremman perhekustannusten tasauksen kuin vähälapsiset tai tulorajan ylittävät perheet. Kun lapsilisä nykyisellään kuitenkin on vain 7.200 markkaa vuodessa elikkä siis vain murto-osa todellisista lapsenkasvatuskustannuksista, ei voida pitää kohtuuttomana, jos lapsiluvun noustessa neljään tasaussumma perhelisälain vaikutuksesta nousee neljänneltä ja sitä seuraavilta lapsilta 7.200 markasta 10.200 markkaan alimmassa kalleusluokassa ja 
11.200 markkaan kalleimmilla paikkakunnilla. Sellaiset perheet, joiden pääasiallinen huoltaja on kuollut, ovat vuoden 1946 puolivälistä alkaen tulleet perhelisästä osallisiksi jo toisesta lapsesta alkaen.

Kun perhelisälaki lapsilisälain voimaan tullessa joutuu tavallaan uuteen asemaan, viimeksimainitun lain täydennykseksi, kiintyy huomio siihen perhelisälaissa alusta saakka olleeseen epäkohtaan, että perhelisästä pääsevät osallisiksi vain ne, joiden tulot ovat määrätyn rajan alapuolella. Tämä rajoitus on vaikeasti perusteltavissa jo siitä syystä, että perhekustannusten tasaus ei ole luonteeltaan köyhäinhoidollinen toimenpide, eikä tasauksen saajan taloudellisen aseman pitäisi siitä syystä vaikuttaa asiaan. Säännös on ollut inflaatiokauden aikana erityisen epäoikeudenmukainen siitä syystä, että raja palkka- ja hintatason noustessa on useasti jäänyt niin alas, että ahkerimmat ja yritteliäimmät työläis- ja pienviljelijäperheet ovat jääneet vaille perhelisää, kun samoissa olosuhteissa elävät huolimattomammat ja saamattomammat perheenhuoltajat ovat tulleet siitä osallisiksi.

Myöskään taloudellisilla syillä ei tulorajaa voída pätevästi puolustaa, koska varakkaammissa perheissä lapsiluku ylittää säädetyn rajan siksi harvoin, että jo tulorajan poistamisesta aiheutuva hallinnon yksinkertaistuminen huomattavasti korvaa niitä lisämenoja, joita tulorajan poistaminen aiheuttaisi. Kun perhelisää on anottava ja se annetaan luontoissuorituksena, on varmaa, että suurin osa varakkaista ihmisistä ei anomusta tekisi. Kysymykseen tulisiyat lähinnä ne, joille rajan olemassaolo on tähän asti tehnyt vääryyttä.

Lapsilisälain täydennyksenä perhelisälaki muodostaa pienten ja keskikokoisten perheiden välille samantapaisen portaan, jollainęn on 1 ja 2 lapsen perheiden välillä niissä maissa, joissa, kuten Norjassa, lapsilisä annetaan vasta toisesta lapsesta alkaen. Perhekustannusten tasauksen tarkoitusta ajatellen olisi johdonmukaisempaa, että tämä porras erottaisi toisistaan kaikki pienet ja keskikokoiset perheet eikä vaikuttaisi vain vähävaraisimpien perheiden kohdalla. 
Kun lapsilisäjärjestelmää ruvettiin luomaan epäonnistuneen perhepalkkauksen tilalle, oltiin laajoissa piireissä sitä mieltä, että uuden lain pitäisi merkitä erilaisten perheenhuoltajille myönnettyjen etujen kokoamista saman nimikkeen alle. Lopputulokseksi kuitenkin jäi, että vain hinnanalennuskortit ja perhepalkkaus poistettiin. Perhelisälain ohella jäivät lapsilisälain säätämisen jälkeen voimaan verotuksen lapsivähennykset, joita myös - lähinnä Ruotsista saadun esimerkin mukaisesti - oli vaadittu tässä yhteydessä poistettaviksi.

Tällainen vaatimus on tietysti paikallaan, jos valtio riittävästi muulla tavoin tukee perheenhuoltajaa. Verotuksen lapsivähennyksethän perustuvat siihen, että lapsenkasvattajaa ei katsota yhtä veronmaksukykyiseksi kuin sellaista huoltovelvollisuutta vailla olevaa henkilöä, jolla on yhtä suuret tulot kuin hänelläkin. Hän saavuttaa kuitenkin saman veronmaksukyvyn sitä mukaa kuin valtio esim. lapsilisän muodossa antaa hänelle verovapaita „tuloja. Sinä hetkenä, jolloin lapsilisä käytännöllisesti katsoen saavuttaa alimpia lapsenelatuskustannuksia vastaavan tason, verovähennykset ovat menettäneet perustelunsa.

Suomessa 1. 10. 48 käytäntöön tullut lapsilisä edustaa kuitenkin varsin vähäistä osaa todellisista lapsenkasvatuskustannuksista. Lapsen aiheuttamia kustannuksia ei talvikautena 19481949 hevin voitane arvioida alhaisemmiksi kuin 80 markaksi vuorokaudelta. Tämä merkitsisi pyörein luvuin 30.000 . markan vuotuiskustannusta. Jos verovelvollinen saisi lukea hyväkseen 7.200 markan Iapsilisän sekä korkeimman mahdollisen verovähennyksen, joka on 3.000 markkaa, ei tasaus vielä nousisi muuta kuin kolmannekseen niistä keskimääräisistä menoista, joita tämän varovaisenkin arvioinnin mukaan lapsesta vuosittain on. Tasaus ei siis muodostunut liian suureksi, vaikka verovähennykset jätettiin lapsilisälain voimaan tultuakin entiselleen. Mikäli verovähennyksiä olisi käyty poistamaan, lapsilisän määrää olisi ollut melkoisesti nostettava, koska säädetty lapsilisä itse asiassa 
jo on pienempi kuin hinnanalennuskortti ja perhepalkkaus yhteensä.

Ne edut, mitä tulo- ja omaisuusverolakimme perheellisyyden perusteella myöntää, eivät kylläkään jakaannu niin oikeudenmukaisesti, etteikö verovähennyskysymystä olisi täysi syy ottaa tarkistettavaksi. Niinpä ensimmäinen lapsi, joka verovähennykssen lisäksi aiheuttaa siirtymisen II veroluokasta III veroluokkaan, merkitsee vuonna 1947 hyväksytyn veroasteikon mukaan jo noin 160.000 markan verotettavan tulon kohdalta lapsilisän suuruista veronvähennystä. Monilapsisessa perheessä, jossa veroluokan vaihtumisesta koituva hyöty on jaettava useampaan osaan, verovähennyksen merkitys luonnollisesti on pienempi, vaikka verovähennys muilta lapsilta onkin 3.000 markkaa ja ensimmäiseltä vain 2.000. Lapsilisälakia valmisteltaessa puolustettiin ensimmäisen lapsen jättämistä lapsilisälain ulkopuolelle sillä, että veroluokan vaihtuminen merkitsee jo varsin huomattavaa tasausetua. Työmarkkinapoliittisista syistä lapsilisää ei kuitenkaan voitu tällä tavalla porrastaa ja kyseenalaista tietenkin onkin, olisiko saavutettujen oikeuksien vähentäminen ollutkaan sopivin keino suuremman oikeudenmukaisuuden aikaansaamiseksi. Toimenpide näet ei olisi kohdistunut pelkästään yksilapsisiin perheisiin vaan vähentänyt jokaisen perheen lapsilisää.

Kun valtiolle lapsilisälakia säädettäessä oli tärkeintä nopeasti ja kohtuullisin kustannuksin selviytyä niistä epäkohdista, joita perhepalkkaukseen liittyi, eikä tarkoituksena voinut olla perheellisille myönnettyjen oikeuksien kaventaminen, kysymys verovähennysten poistamisesta oli niin valtiolle kuin perheenhuoltajallekin muotoseikka. Oli miellyttävämpää antaa osa tasauksesta entiseen tapaan veronvähennyksenä, jotta tulo- ja menoarvion numerot eivät aiheettomasti kasvaisi. Siksipä eduskuntakaan ej-pitänyt verotukseen sisältyvien epätasaisuuksien korjaamista välttämättömänä lapsilisän säätämisen yhteydessä.

Myöhemmin, kun lapsilisälaista ehditään saada käytännöllisiä kokemuksia ja verolakeja muistakin syistä. joudutaan korjaamaan, saattaa olla paikallaan harkita sellaista teknillistä jär- 
jestelyä, joka sopivalla tavalla liittää verotuksen ja lapsilisäjärjestelmän toisiinsa, jotta valtion ei samanaikaisesti tarvitse antaa ja ottaa, vaan tarpeellinen tilienselvittely tapahtuu valtion virastossa. Se edellyttää lapsilisien korottamista, ja koska korotuksen ilmeisesti pitää olla riippumaton perheen varallisuudesta, se merkitsee lisäetua niille, jotka tällä kertaa eivät nauti sellaisia tuloja, että heidän verojaan voitaisiin korkeimmalla mahdøllisella summalla vähentää.

Paljon suuremmalla syyllä kuin tulo- ja omaisuusveron lapsivähennyksiä voitaisiin epäilemättä vaatia kunnallisveron lapsivähennyksiä lapsilisällä korvattavaksi. Tätä kautta saatava perhekustannusten tasaus on nimittäin tavattoman epätasainen maan eri osissa. Olojen erilaisuuden takia verolainsäätäjä ei ole voinut määrätä lapsivähennystä samaksi koko maassa, vaan kunnanvaltuustolle on jätetty valta määrätä lapsivähennys tiettyjen rajojen puitteissa. Niinpä vaihtelee lapsivähennys vuoden 1947 säännösten mukaan maalaiskunnissa 8.000 markasta 15.000 markkaan ja kaupunkikunnissa 12.000 markasta 18.000 markkaan. Varsinkaan maan itä- ja pohjoisosien lapsirikkaissa kunnissa, joissa väestö on köyhää, valtuustolla ei ole mahdollisuuksia korkeimman mahdollisen lapsivähennyksen käyttämiseen, koska liian monien kuntalaisten verotettavat tulot saattaisivat silloin laskea toimeentulominimin alapuolelle ja verojen jääminen entistä harvempien kuntalaisten maksettavaksi merkitsisi veroäyrin ja verorasituksen kohtuutonta nousua.

Tämän takia voi hyvin olla mahdollista, että sellaisessa kunnassa, jossa veroäyri on esim. 10 markkaa, käytetään korkeinta 15.000 markan lapsivähennystä, jonka reaaliarvoksi tällöin tulee 1.500 markkaa. Toisessa kunnassa, jonka veroäyri on samansuuruinen, saatetaan käyttää pienintä mahdollista eli 8.000 markan verovähennystä, jolloin lapsivähennys alentaa veroa vain 800 markalla. Tällaista epätasaisuutta ei voida korjata eikä tarjota kaikille lapsenkasvattajille samansuuruista perhekustannusten tasausta, ellei järjestetä lapsilukuun perustuvaa kunnallisen verorasituksen tasoitusta tai sitten poisteta kunnallisveron lapsivähennyksiä ja korvata niitä lapsilisän määrää nostamalla. 


\section{Rahoitustapa.}

Perhekustannusten tasaus on eri maissa rahoitettu tai pyritty rahoittamaan varsin erilaisilla tavoilla. Perhepalkkauksessa kustannus sälytetään välittömästi työnantajalle, joka tuotteittensa hintaa korottamalla koettaa siirtää sen edelleen. Sosiaalivakuutuksen luontoisissa järjestelmissä kustannuksiin osallistuvat työnantajien ohella useasti vakuutetut itse. Toisinaan on niissä valtio kolmantena. Siellä, missä Suomen järjestelmän tapaan valtio yksinään vastaa kustannuksista, kysymys lapsilisiin tarvittavien varojen hankinnasta liittyy yleiseen valtion toiminnan rahoitukseen. Se on osa verojärjestelmää ja sellaisena arvosteltava.

Runsas kolmannes niistä varoista, mitä lapsilisien rahoitukseen meillä tarvitaan, laskettiin saatavan valtion tulo- ja menoarvion puitteissa toimitettavilla järjestelyillä, mutta melkein kaksi kolmannesta säädettiin kuitenkin hankittavaksi tavalla, joka liittyy lapsilisäjärjestelmään kiinteämmin kuin jokin verojärjestelmän osa yleensä. Niinkuin edellä jo on mainittu, perhepalkkausjärjestelmän perintönä saatiin uusi vero, lapsilisämaksu. Se on tyypillinen käyttötarkoitusvero, eivätkä kokemukset tämänlaatuisesta verosta jonkin sosiaalisen menon rahoittajana ole ollenkaan myönteiset. Tällaista veroa suorittaessaan tulee varonmaksaja säännöllisin väliajoin kiinnittäneeksi huomionsa siihen tarkoitukseen, johon hän tietää rahojensa tulevan käytetyksi, eikä tämä ole omiaan tekemään häntä suopeaksi perhekustannusten tasaukselle, varsinkaan jos hän ei henlkilökohtaisesti mitenkään tästä tasauksesta hyödy. Tällaista aatteellista kitkaa ei synny, jos perhekustannusten tasaus rahoitetaan valtion yleisistä varoista, jolloin veronmaksaja ei tiedä, mihin menoihin juuri mikin hänen suorittamansa erä käytetään.

Lapsilisämaksun ollessa eduskuntakäsittelyn alaisena kiinnitettiin myös huomiota siihen, että tämäntapaisen veron aiheuttama rasitus siirtyy varsin eri tavalla eri tuottajaryhmiltä kuluttajien kannettavaksi. Varsinkin hintasäännöstelyn vallitessa on ilmeistä, että teollisuudenharjoittajain, joiden tuotteiden hinnat 
määrätään kustannuslaskelmien perusteella, on helpompi saada lapsilisän käytäntöönotosta koituva rasitus otetuksi hinnassa huomioon kuin maataloustuottajain, koska maataloustuotteiden hintoja määrättäessä kustannuslaskelmat näyttelevät paljon vaatimattomampaa osaa kuin teollisuustuotteiden kohdalla on asian laita. Vapaan talouden vallitessa tämänlaatuiset epäkohdat luonnollisesti aikaa myöten tasaantuisivat, mutta hinta- ja palkkasäännöstelyn vallitessa näkökohta on varsin huomionarvoinen.

Eduskunnan kanta on käsittääkseni niin ymmärrettävä, että väliaikaiseksi säädettyä lapsilisämaksua on pidettävä hätäratkaisuna, josta määrävuosien kuluttua luovutaan, kun valtio vapautuu eräistä sen taloutta tällä kertaa painavista tilapäisluontoisista rasituksista ja voi varata tarkoitukseen suositeltavammin keinoin hankittuja verovaroja. .Lapsilisän suorittaminen ei niin paljon eroa muista valtion itselleen ottamista varoja vaativista sosiaalisista tehtävistä, että sen rahoittamisessa olisi syytä turvautua tällaiseen poikkeukselliseen verotusmuotoon. Kun näin on, täytyy katsoa, että lapsilisän rahoittamisella ei ole edellytyksiä säilyä erikoisprobleemina, vaan on siihen tarvittavia rahoja hankittaessa pidettävä silmällä verojärjestelmän aiheuttamaa kokonaisrasitusta, kuten kaikessa muussakin verotulojen hankinnassa.

Lapsilisän suuruus.

Niinkuin lapsilisälain syntyhistoriasta ilmeni, lapsilisän suuruutta eivät meillä määränneet mitkään tasaustarpeen suuruuteen perustuvat arvioinnit vaan puhtaasti käytännöllistä laatua olevat valtion finanssiasemaan perustuvat näkökohdat. Samantapainen on ollut asian ratkaisu muissakin maissa. Niinpä Ruotsissa tultiin erilaisilla laskelmilla, kuten asiaa koskevassa tämän julkaisun seuraavassa artikkelissa selostetaan, siihen tulokseen, että lapsen aiheuttamat kustannukset ovat noin 800 kruunua vuodessa, mutta lapsilisän määrääminen 260 kruunuksi ei pohjautunut erityisemmin mihinkään käsitykseen siitä, kuinka 
suuri osa kustannuksista olisi pyrittävä tasaamaan, vaan ratkaisun sanelivat lähinnä näköpiirissä olevat rahoitusmahdollisuudet.

Kun otetaan huomioon, että meillä lapsilisän ohella ovat voimassa verovähennykset ja suurempien perheiden kohdalla perhelisälakikin korottaa tasauksen määrää, voitaneen sanoa, että meillä Suomessa tasaus saattaa sivuuttaa kolmanneksen alimmista ajateltavissa olevista lapsenkasvatuskustannuksista. Ruotsissa, jossa erilaiset luontoisavustusmuodot ovat lukuisammat, korvattaneen ainakin puolet alimmista kustannuksista.

Verraten usein näkee näiden kysymysten yhteydessä viitattavan ihmisen luontaiseen haluun saada lapsia ja huomautettavan, että tasaus ei saisi nousta perhekustannusten koko määrään, koska silloin saattaisi käydä esim. siten, että lasten kasvattamisesta kehittyy uusi toimeentulon muoto. Ihmiset, jotka enemmän tai vähemmän vieroksuvat varsinaista työtä, saattavat lisätä lapsilukuaan tullakseen toimeen siten, että perhe tyytyy alhaisempaan elintasoon, mikä tasaussummaa määriteltäessä on lapsilla edellytetty olevan. Kun tällainen ihmistyyppi ei rodullisesti edusta sellaista ainesta, jonka lisääntymimen olisi suotavaa, on viitattu siihen, että liian suuret tasaukset täten voivat vaikuttaa turmiollisesti.

Mahdoton edelläesitetty kaavailu ei luonnollisestikaan ole, mutta verraten teoreettisena sitä kuitenkin on pidettävä niin kauan kuin tasaus liikkuu tähänastisissa suuruusluokissa. Sensijaan lienee puhtaasti taloudellisestikin ajatellen aiheetonta pyrkiä kovin suureen tasaukseen. Onhan selvää, että tasaussummia eivät maksa valtiolle veroina vain lapsettomat ja vähälapsiset. Mitä suurempi osa vuotuisesta kansantulosta tarvitaan lapsilisiin ja muihin tasausmuotoihin, sitä enemmän kaventuu se osa, josta muut tulot saadaan. Näin ollen on varsinkin sellaisessa yhteiskunnassa, jossa tulon jakaantuminen ei ole kovin epätasainen eikä perheiden koko kovin vaihteleva, ilmeisesti katsottava varsin tyydyttäväksi, jos runsaasti puolet lasten aiheuttamista kustannuksista voidaan tasaustietä korvata. 
Väestönkehitys maassamme olisi terveellä kannalla, jos neljännet ja viidennet lapset tulisivat yleisemmiksi. Jos lasketaan, että ilman tasausta elintaso on sellainen, että parin kolmen lapsen kasvattaminen ei tuota suurempia vaikeuksia, edellämainittu puolen tasaus johtaisi siihen, että $4-5$ lapsen perheet olisivat mahdollisia alentamatta liikaa vanhempien elintasoa.

\section{Lapsilisän yksityistaloudellinen vaikutus.}

Vaikka lapsilisä ei yksikseen eikä yhdessä perhelisän kanssa edustaisikaan kuin neljännestä tai parhaassa tapauksessa kolmannesta alimmista ajateltavissa olevista elinkustannuksista, se merkitsee kuitenkin varsin huomattavaa parannusta lapsenkasvattajan toimeentuloon. Asettaahan se neljän lapsen huoltajan samaan asemaan kuin missä kolmen lapsen huoltaja aikaisemmin on ollut, varsinkin kun neljännestä lapsesta saadaan vähävaraisissa kodeissa myös perhelisä. Siellä, missä eletään lähellä luontoa, missä on oma asunto ja suurin osa elintarvikkeista saadaan omasta pellosta tai karjasta, ei kaikissa tapauksissa suurempi rahallinen tasausmaksu olisi puolustettavissakaan. On nimittäin huomattava, että esim. 8 lapsen äiti saa joka kuukausi 4.800 markkaa käteistä, vaikka ei perheen isä millään tavalla osallistuisi lastensa elättämiseen. Kokemuksesta tiedetään, että niissä osissa maata, joissa lapsirikkaus on yleisintä, esiintyy myös paljon taloudellista vastuuttomuutta. Työtä ei tehdä elintason parantamiseksi, vaan välttämättömimmän toimeentulon takia. Jos eläminen muulla tavalla tulee turvatuksi, savottaan lähtö tai muut ansiotoimet saattavat mieheltä jäädä.

Tätä mahdollisuutta ajatellen ja lukuisien vapaitten huoltojärjestöjen kokemuksista viisastuneina säädettiin perhelisä aikanaan annettavaksi luontoissuorituksina ja nimenomaan siinä hengessä, että voitaisiin näillä rahoilla panna toimeen perusparannuksia. Niin myönteisiä kokemuksia kuin luontoissuoritustavasta perhelisälain yhteydessä on saatukin, ei kuiten- 
kaan ole ajateltavissa, että samaa menetelmää voitaisiin toteuttaa lapsilisälakia toimeen pantaessa. Ainoa, mitä voidaan ajatella ja mikä myös näyttää välttämättömältä, on neuvonnan kaikinpuolinen tehostaminen. Neuvonnassa on pyrittävä siihen, että lapsilisälain tuomia uusia verovapaita tuloja ei käytettäisi jokapäiväiseen kulutukseen, vaan nimenomaan perusparannuksiin. Mikäli perhelisäperheiden kohdalla neuvonnan antamia herätteitä kehittäen on tehty suunnitelmia oman elintarviketuotannon aikaan saamiseksi, asunnon korjaamiseksi, ammattikasvatuksen antamiseksi lapsille yms., näitä suunnitelmia voidaan nyt monin verroin paremmin toteuttaa, kun niukkojen perhelisävarojen ohella käytetään tarkoitukseen myös huomattavasti suurempia lapsilisävaroja. Onhan suhde sellainen, että esim. edellämainittu 8 lapsen perhe saa vuodessa perhelisävaroja vain 15.000 , mutta lapsilisävaroja se saa lähes 60.000 markkaa.

Ruotsissa ovat säästölaitokset pyrkineet siihen, että lapsilisä talletettaisiin lapsen nimelle pankkiin. Meillä ovat sekä Postisäästöpankki, jonka kautta lapsilisät jaetáan, että pankit, säästöpankit ja osuuskassat alkaneet mainostaa samaa menettelytapaa. Kun lapsirikkaiden perheiden on tähän saakka ollut vaikea tehdä minkäänlaisia säästöjä vastaisen varalle, lapsilisän tarjoama mahdollisuus on varsin huomion arvoinen, mikäli on kysymys perheestä, joka voi muilla tuloillaan huolehtia siitä, että lapset saavat tyydyttävän ravinnon, vaatetuksen ja asunnon. Varsinkin niin kauan kuin lapsiluku on pieni, tällainen säästäminen on erityisen suositeltavaa, koska silloin vanhemmilla yleensä järkevästi talouttaan hoitaen on mahdollisuus itse huolehtia lastensa toimeentulosta.

Kansantaloudellinen vaikutus.

Kehoitus lapsilisän tallettamiseen on kansantalouden kannalta erityisen suositeltava. Lapsilisälain edellyttämä valtion keräämien rahavarojen jakaminen yksityisille merkitsee ku- 
lutusmahdollisuuksien lisäämistä niissä perheissä, joissa nämä mahdollisuudet ovat olleet niukimpia. Se merkitsee siis kulutuksen lisäämistä ja pääomanmuodostuksen vastaavaa supistumista. Vaikka tästä johtuva kulutuksen lisäämismahdollisuus useissa tapauksissa merkitsee kansakunnan kannalta mitä edullisinta pääoman sijoitusta, kun aliravitut lapset saavat paremman ravinnon ja kunnollisen vaatetuksen, lapsilisää saavien perheiden joukossa on luonnollisesti myös paljon niitä, joiden elintaso nykyisellään vastaa kansamme tämänkertaisia mahdollısuıksia. Kun pääomanmuodostus on kansan taloudellisen edistymisen kannalta välttämätöntä, siitä huolehtiminen on lähinnä katsottava näiden perheiden asiaksi. Sentähden olisi varsin tärkeätä, että nämä perheet saataisiin mahdollisimman suuressa määrässä säästämään lapsilisänsä lapsien nimelle näiden tulevaa ammattikasvatusta tai muuta vastaavanlaista tarvetta varten tai itse sijoittamaan ne tuottavaan tarkoitukseen. Kansantalouden kannalta on tärkeätä saada vastapainoa sille kulutuksen lisääntymiselle, mitä lapsilisän kaltainen jakaantumispoliittinen toimenpide aiheuttaa lisätessään sellaisten henkilöiden kulutusmahdollisuuksia, joiden kulutus on ollut tähänastisella tasollaan vain välttämättömyyden pakosta.

Monilapsisella perheellä ei ole samanlaisia mahdollisuuksia säästää pahan päivän varalle kuin pienellä perheellä, vaikka säästöjen tarpeellisuus ensinmainitussa kieltämättä on suurempi. Tästä syystä olisikin kansantalouden terveen kehityksen kannalta suotavaa, että lapsilisän tapaiseen perhekustannusten tasaukseen voitaisiin yhdistää riittävästi säästäväisyyspropagandaa, jotta edes jokin osa vuosittain jaetusta yli 8 miljardin suuruisesta summasta tulisi säästetyksi ja sillä tavalla edistetyksi pääomanmuodostusta. Tulosten saavuttamiseksi olisi kuitenkin välttämätöntä kiinnittää perheiden huomio sopiviin säästämisen kohteisiin ja antaa niille tukea päämäärän saavuttamisessa. Erikoisen suositeltava tavoite olisi tällöin oma koti, koska asuntopula tulee vielä pitkän aikaa vaivaamaan asutuskeskuksiamme ja koska jokainen oman kodin hyväksi säästetty markka merkitsee, että rakennustoimintaan tarvitaan en- 
tistä vähemmän varoja niistä pääomalähteistä, jotka varsinaista tuotantotoimintaa rahoittavat.

Pitkällinen inflaatiokausi on suuresti laimentanut yksityisten kansalaisten säästämishalua ja vastaavasti vähentänyt niitä pääomavaroja, joita kansallamme on käytettävissään. Jos lapsilisälain yhteydessä onnistuttaisiin uudelleen elvyttämään säästäväisyyttä oman kodin hankkimisen merkeissä, valtiovallalla olisi täysi syy harkita erikoisetujen myöntämistä tällaisille säästämisen muodoille. Näin ei autettaisi yksin kansantaloutta, vaan myös lapsenkasvattajain yksityistaloutta.

Lapsilisälaki merkitsee valtion puuttumista entistä tiukemmin tulojen jakaantumiseen. Valtiolla on mahdollisuuksia vaikuttaa tuloja tasaavasti sekä varoja hankkiessaan että niitä käyttäessään. Merkittävin tekijä hankintapuolella on olluit progressiivinen verotus, jonka avulla keskikokoisten ja suurten tulojen saajia on viime vuosina pidetty varsin tiukalla. Ovatpa sen kouriin inflaatiokehityksen johdosta joutuneet sellaisetkin laajat kansankerrokset, joiden tuloissa ei oikeastaan mitään tasaamista ole ollut. Lapsilisälain aiheuttamiin menoihin verraten ovat tähänastiset menopuolella käytetyt tasauskeinot olleet suhteellisen vaatimattomia. Sosiaaliministeriö arvioi julkaisussaan »Sosiaalinen lainsäädäntö ja toiminta Suomessa», että valtion sosiaalimenot olivat vuonna 1946, jos lääkintölaitoksen menot otetaan mukaan, noin 3.800 milj. markkaa. Kuntien arvioidaan samanaikaisesti käyttäneen sosiaalisiin tarkoituksiin noin 2.000 milj. markkaa. Kun työnantajat tämän lisäksi ovat.uhranneet huomattavasti varoja sosiaalisiin tarkoituksiin, mainittu julkaisu arvioi sosiaalisen työn kokonaiskustannukset vuonna 1946 noin 7 miljardiksi markaksi. Vaikka otetaankin huomioon hintatason nousu, jonka ansiosta vastaavat kustannukset saattavat nyt olla $10-12$ miljardia vuodessa, merkitsee lapsilisiin käytettävä 8,2 miljardia kuitenkin aivan mullistavaa lisäystä niihin varoihin, jotka valtio vuosittain käyttää tasatakseen kansalaisten tuloja.

Yksipuolisesti pääomanmuodostukseen tuijottava taloudellinen tarkastelu jättää useasti huomiotta sen, että lisääntynyt 
kulutus, minkä lapsilisän tapainen jakaantumispoliittinen toimenpide aiheuttaa, merkitsee toisaalta myös kysynnän kasvamista ja sitä tietä tuotantomahdollisuuksien lisääntymistä. Kulutuksen kasvaessa lisääntyy työllisyys ja taloustoiminnan varsinainen tarkoitus toteutuu entistä paremmin.

Huomion arvoinen on myös lapsilisälain vaikutus kuntien talouteen, vaikka siitä tätä kirjoitettaessa ei vielä ole numeroaineistoa käytettävissä. Kun syntyneisyys maan köyhissä itäja pohjoisosissa on hyvin paljon suurempi kuin länsi- ja eteläosissa, tästä johtuu, että lapsirikkaus merkittävällä tavalla kärjistää sitä varallisuuseroa, mikä luontaisista edellytyksistä johtuen maan eri osien välillä on. Suurempi lapsiluku aiheuttaa itäisten ja pohjoisten seutujen kunnille monia sellaisia menoja, joista varakkaammat kunnat muualla maassa välttyvät. Lapsilisälaki merkitsee, että tällaisten kuntien lastenkasvattajat saavat vuosittain uutta ostovoimaa kunnan koosta riippuen 10 - 50 milj. markkaa. Tämä seikka ei voi olla tuntumatta näitten kuntien taloudellisissa oloissa, sillä vaikka lapsilisät itse ovat verovapaita, ne aiheuttavat liikkeeseen päästessään kuitenkin kunnan piirissä niin huomattavien veronalaisten tuloerien syntymisen, että tämä tuntuu kunnan verotuloissa, puhumattakaan siitä, että lapsilisä jo välittömästi vaikuttaa köyhäinhoitomenojen vähenemiseen. Näin vaikuttaa lapsilisälaki jakaantumiseen myös maantieteellisessä mielessä.

\section{Järjestelmän kehittäminen.}

Laki myöntää valtioneuvostolle oikeuden korottaa lapsilisää, mikäli elinkustannukset kohoavat, mutta reaaliarvon korottaminen on eduskunnan asia, milloin se tapahtuu markkamäärää suurentamalla. Lapsilisämaksu, jolla pääosa varoista ainakin alkuvuosina hankitaan, on rakenteeltaan sellainen, että sen tuotto kasvaa sekä palkkatason noustessa että työllisyyden lisääntyessä. 
Kun mahdollisen inflaation vaikutukset näin voidaan korjata ilman lain muutosta, onkin todennäköistä, että kysymys pitemmälle ulottuvasta perhekustannusten tasauksesta tulee ensiksi esille joko siinä muodossa, että perhelisä tehdään yleiseksi poistamalla sen saantia rajoittava tuloraja, tai sitten tarkistetaan verotuksen lapsivähennykset ja mahdollisesti korvataan tätä tietä menetetty etu suuremmalla lapsilisällä. Tällaiseen uudistukseen voi antaa aiheen se, että tulo- ja omaisuusverolaki joutuu muusta syystä tarkistettavaksi tai kauan suunnitteilla ollut kunnallisverotuksen uudistus saadaan aikaan.

Harkinnan arvoinen on myös kysymys siitä, millä tavalla lapsilisäjärjestelmä ja valtion asuntopolitiikka mahdollisesti olisivat toisiinsa kytkettävissä. Edellä olen jo viitannut siihen, että tällä pohjalla ehkä olisi mahdollisuuksia säästäväisyyden edistämiseen ja samanaikaisesti asunto-olojen parantamiseen. Mikäli ne kokemukset, jotka lähivuosina lapsilisälaista saadaan, viittavat siihen, että luontoissuoritus olisi lapsilisissäkin otettava käyttöön mieluummin kuin käteissuorituksia nykyisestään lisättävä, asuntopolitiikka tarjoaa tässä suhteessa varsin suuria mahdollisuuksia. Monessa maassa, kuten esim. Ruotsissa, näyttelee vuokra-alennusten tai rakennuslainojen muodossa annettu tuki jo nyt varsin huomattavaa osaa perhekustannusten tasauksessa. Lapsilisä on siksi suuri sosiaalinen uudistus, että kovin pitkälle sen kehittämistä on aiheetonta ennakolta kaavailla, ennenkuin on saatu riittävästi kokemuksia sen vaikutuksesta niin lapsenkasvattajain yksityistalouteen ja valtion talouteen kuin kansantalouteen kokonaisuudessaankin. 